\title{
PENGEMBANGAN SISTEM NANOSTRUCTURED LIPID CARRIER (NLC) DAUN Chrysanthemum cinerariifolium (Trev.) Vis DENGAN VARIASI KONSENTRASI LIPID
}

\author{
Anik Listiyana ${ }^{1}$, Roihatul Muti'ah ${ }^{2}$, Arief Suryadinata ${ }^{2}$, dan Farida Rahma Salsabilla ${ }^{2 *}$ \\ ${ }^{1}$ Program Studi Kedokteran Fakultas Kedokteran dan Ilmu Kesehatan Universitas Islam Negeri Maulana \\ Malik Ibrahim Malang, Indonesia. \\ ${ }^{2}$ Program Studi Farmasi Fakultas Kedokteran dan Ilmu Kesehatan Universitas Islam Negeri Maulana \\ Malik Ibrahim Malang, Indonesia.
}

\begin{tabular}{|c|c|}
\hline & $\boldsymbol{d} b \operatorname{stract}$ \\
\hline $\begin{array}{l}\text { Keyword: } \\
\text { Nanostructured } \\
\text { Lipid Carrier } \\
\text { (NLC); } \\
\text { Lipids; } \\
96 \% \text { ethanol } \\
\text { extract of } \\
\text { Chrysanthemum } \\
\text { cinerariifolium } \\
\text { (Trev.) Vis } \\
\text { leaves; } \\
\text { Characterization. }\end{array}$ & $\begin{array}{l}\text { Ethanol extract } 96 \% \text { of Chrysanthemum cinerariifolium (Trev.) Vis leaves are proven to } \\
\text { have anticancer activity. However, these compounds have low solubility in water and fat. } \\
\text { To improve the bioavailability of preparations, the development of drug design in the form } \\
\text { of Nanostructured Lipid Carrier (NLC) is carried out.The aim this study was to determine } \\
\text { the effect of differences in lipid concentration of Monostearin and Oleic Acid in the } \\
\text { formulation of the NLC system of Chrysanthemum cinerariifolium (Trev.) Vis leaves, which } \\
\text { produced good physicochemical characteristics including organoleptic characteristics, } \mathrm{pH} \text {, } \\
\text { viscosity, particle size, and drug entrapment efficiency. Making is done using the High } \\
\text { Shear Homogenization method. Organoleptic tests showed ideal results for the } \\
\text { Nanostructured Lipid Carrier (NLC) system, the resulting pH values in formula } 1 \text { (7.0 } \pm \\
\text { O.12), formula } 2(6.7 \pm 0.17) \text { and formula } 3 \text { (6.8 } \pm 0.2) \text { ), the viscosity value of formula } 1 \\
\text { (55.66 } \pm 2.84 \text { cPs), formula } 2(28.86 \pm 3.91 \text { cPs), and formula } 3 \text { (28.57 } \pm 16.85 \text { cPs). } \\
\text { Particle size of formula } 1 \text { (5530 } \pm 320.47 \text { nm), formula } 2 \text { (5337 } \pm 671.44 \text { nm) and formula } \\
3 \text { (4676 } \pm 2215.75 \text { nm)). The entrapment efficiency value of formula } 1 \text { drugs (33.55\%), } \\
\text { formula } 2 \text { (38.77\%), formula } 3 \text { (83.75\%). Based on the characterization result, the best } \\
\text { formula was obtained at a lipid concentration of } 10 \% \text {, which was used for the formula of } \\
\text { the NLC system of Chrysanthemum cinerariifolium (Trev.) Vis leaves for oral anticancer } \\
\text { preparations }\end{array}$ \\
\hline
\end{tabular}

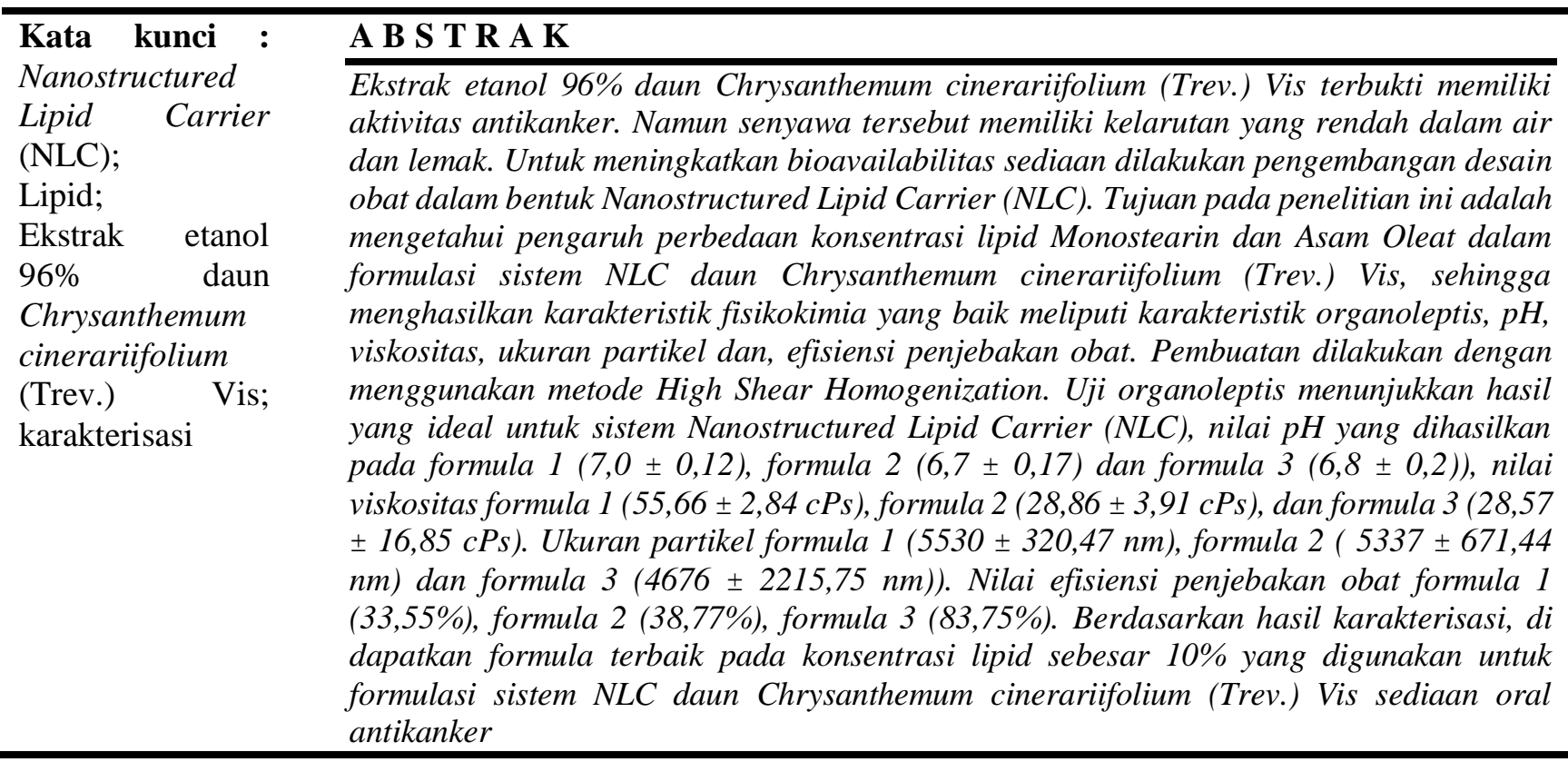

*Corresponding author

Email: salsaphalida49@gmail.com 


\section{PENDAHULUAN}

Nanostructured Lipid Carrier (NLC) adalah sistem berbasis lipida yang menggunakan kombinasi matriks berupa lipid padat dan cair yang distabilkan dengan penambahan surfaktan (1). Pengembangan sistem NLC ditujukan untuk memperbaiki beberapa permasalahan yang timbul pada sistem Solid Lipid Nanoparticle (SLN) yaitu jumlah penjerapan obat yang terlalu rendah, keluarnya obat dari sistem selama masa penyimpanan, dan kandungan air yang terlalu tinggi pada dispersi SLN (2). Sistem NLC memiliki kelebihan yaitu kemampuan enkapsulasi yang tinggi, rilis yang terkontrol, stabil secara termodinamik dan mampu meningkatkan bioavailabilitas senyawa bioaktif (3). Sistem NLC juga banyak diaplikasikan pada bidang farmasi, karena kemampuannya menghantar obat sampai ke target dan juga mampu mengontrol rilis obat, dengan ukuran partikel nano menyebabkan komponen bioaktif dapat lebih akurat langsung mencapai sel target atau reseptor dalam tubuh (4).

Dalam pembuatan sistem NLC sangat memperhatikan sifat-sifat dan bahan yang digunakan dalam formulasinya, karena sangat berpengaruh terhadap karakteristik fisikokimia formula NLC seperti organoleptis, nilai $\mathrm{pH}$, ukuran partikel, viskositas, dan efisiensi penjebakan obat yang nantinya menentukan efektifitas sistem NLC dalam membawa senyawa bioaktif (5). Komposisi utama yang perlu diperhatikan yakni pemilihan fase lipid yang akan digunakan, diantaranya titik lebur, morfologi kristal, viskositas, dan polaritas (6). Lipid sebagai kerangka dasar pembentuk NLC menentukan karakteristik akhir NLC, terutama pada stabilitasnya. Lipid padat lebih memiliki peran yang dominan dalam membentuk stabilitas sistem, pada penelitian ini lipid padat yang digunakan adalah monostearin.Lipid padat akan dikombinasikan dengan lipid cair yakni asam oleat.

Monostearin memiliki kelebihan dibandingkan dengan penggunaan lipid padat lain seperti gliseril behenate maupun setil palmitat. Monostearin memiliki bentuk polimorf yang stabil serta memiliki potensi yang rendah untuk berubah bentuk dari satu bentuk ke bentuk polimorf lain (7). Lipid padat akan dikombinasikan dengan lipid cair, salah satu lipid cair yang sering digunakan dalam kombinasi matriks lipid NLC adalah asam oleat. Asam oleat memiliki rumus molekul $\mathrm{C}_{18} \mathrm{H}_{34} \mathrm{O}_{2}$, merupakan asam lemak rantai lurus beratom karbon 18 yang memiliki satu buah gugus karboksilat pada salah satu ujungnya. Asam oleat termasuk monosaturated fatty acid, yakni asam lemak tak jenuh. Asam lemak tak jenuh, membuat emulsi pada sistem lebih stabil, sehingga dapat meningkatkan stabilitas sediaan NLC (8). Penggunaan asam oleat sebagai lipid cair juga berperan penting dalam menurunkan proses kristalisasi dan merupakan faktor utama yang mempengaruhi kecepatan pelepasan bahan aktif dan efisiensi penjebakan obat dalam sistem NLC (9). Perbedaan titik lebur merupakan poin penting dalam pemilihan lipid pada sistem NLC. Perbedaan titik lebur antara lipid padat dan lipid cair mempengaruhi proses kristalisasi, yang secara langsung berhubungan terhadap pembentukan fase solid-state pada permukaan partikel NLC ketika penurunan suhu (10). Lipid padat akan membentuk kristal lebih awal di permukaan partikel, kemudian lipid cair akan berada pada inti partikel bersama bahan aktif sehingga dapat meningkatkan stabilisasi bahan aktif. Pada sistem NLC, lipid padat dan lipid 
cair akan membentuk struktur kristal yang tidak sempurna. Hal ini menyebabkan matriks yang terbentuk akan memuat obat dalam jumlah yang lebih tinggi sehingga kemungkinan bahan aktif keluar dari sistem juga dapat dikurangi atau bahkan dihindari (10). Beberapa senyawa yang tidak stabil dapat dihantarkan dengan sistem NLC ini terutama senyawa antioksidan (10).

Seiring perkembangan teknologi, pada penelitian ini akan digunakan sistem NLC menggunakan lipid padat monostearin dan lipid cair asam oleat dengan perbandingan $6: 4,12: 8,18: 12$ menggunakan bahan obat yang berasal dari ekstrak bahan alam. Ekstrak bahan alam, dikenal memiliki manfaat untuk mengobati suatu penyakit tertentu. Ekstrak-ekstrak tersebut, didapatkan dari tumbuhan obat yang mengandung suatu senyawa bioaktif yang dapat memberikan efek farmakologis. Salah satu ekstrak yang telah terbukti memiliki efek farmakologis yakni antikanker adalah ekstrak daun Chrysanthemum cinerariifolium (Trev.) Vis. Ekstrak daun Chrysanthemum cinerariifolium (Trev.) Vis berwarna hijau, memiliki tekstur yang kental serta pekat. Penelitian terbaru, menyebutkan bahwa dalam ekstrak daun Chrysanthemum cinerariifolium (Trev.) Vis memiliki senyawa antioksidan golongan flavonoid dan flavonol meliputi Kaempferitin, Isorhamnetin, Genistein, Orphenadrin dan Kaemferol (11). Senyawa tersebut memiliki aktivitas sitotoksik terhadap sel T47D dengan nilai IC $_{50}$ sebesar 362,58 $\mu \mathrm{g} / \mathrm{ml}$ (11). Namun, bioavailabilitas oral flavonoid relatif rendah karena lipofilitas rendah dan kelarutan air yang buruk, sehingga membatasi kemampuan senyawa melewati membran biologis

\section{Bahan Penelitian}

Bahan - bahan yang digunakan dalam penelitian ini bila tidak dinyatakan lain, yang kaya lipid (12). Diperkirakan $40 \%$ atau lebih ekstrak bahan alam memiliki kelarutan yang rendah dalam air dan memiliki toksisitas yang tinggi. Hal tersebut, dapat mempengaruhi bioavailabilitas suatu senyawa bahan alam di dalam tubuh. Tidak hanya itu, bioavailabilitas suatu senyawa juga sangat dipengaruhi oleh stabilitas senyawa terhadap $\mathrm{pH}$ tubuh, metabolisme oleh mikroflora normal dalam saluran pencernaan dan absorpsi melalui dinding usus (13). Oleh sebab itu, penting melakukan pengembangan formula yang dikenal dengan Novel Drug Delivery System (NDDS) salah satunya, sistem Nanostructured Lipid Carrier (NLC) guna mengurangi toksisitas, meningkatkan aktivitas farmakologi, meningkatkan kelarutan, meningkatkan stabilitas, melindungi dari $\mathrm{pH}$ ekstrem, memperbaiki biodistribusi dan mencegah terjadinya degradasi fisik ataupun kimia (13).

Berdasarkan uraian tersebut, maka pada penelitian ini dilakukan uji karakterisasi pada sistem penghantaran obat Nanostructured Lipid Carrier (NLC) dengan menggunakan monostearin sebagai lipid padat dan asam oleat sebagai lipid cair dengan perbandingan lipid 10\%; 20\%;30\% menggunakan ekstrak etanol $96 \%$ daun Chrysanthemum cinerariifolium (Trev.) Vis. Evaluasi yang dilakukan pada penelitian ini adalah karakteristik fisikokimia yang meliputi uji organoleptik, $\mathrm{pH}$, viskositas, ukuran partikel, dan efisiensi penjebakan. Dari formula tersebut, diharapkan terbentuk formula yang ideal sehingga dapat memberikan efek terapi yang baik.

\section{METODE PENELITIAN}

memiliki kemurnian memenuhi standar USP dan biasanya digunakan untuk kebutuhan pembuatan sediaan farmasi (pharmaceutical grade). Bahan utama 
yang digunakan dalam penelitian ini adalah ekstrak etanol $96 \%$ daun Chrysanthemum cinerariifolium (Trev.) Vis yang didapatkan dari Desa Punten Kota Batu Jawa Timur, Monostearin (Merck), Asam Oleat (Sigma Aldrich), Tween 80 (PT.Croda), Span 80 (PT Croda), Etanol 96\% (Merck), dapar fosfat $\mathrm{pH} \quad 7,4$ dibuat dari $\mathrm{KH}_{2} \mathrm{PO}_{4}$ (kalium dihidrogen fosfat) dan $\mathrm{NaOH}$ (natrium hidroksida) (Merck).

\section{Pembuatan Sistem NLC Ekstrak Etanol 96\% Daun Chrysanthemum cinerariifolium (Trev.) Vis}

\section{Formula}

Sistem NLC ekstrak etanol 96\% daun Chrysanthemum cinerariifolium (Trev.) Vis dibuat dengan perbandingan lipid yang berbeda untuk menghasilkan berat sebesar 20,0 g dan replikasi dilakukan sebanyak tiga kali. Sistem NLC diharapkan memiliki karakteristik organoleptis yang ideal dengan $\mathrm{pH}$ 4-7, viskositas 32,5-2499,5 cPs, ukuran partikel 10-1000 nm, dan efisiensi penjebakan 30-99\%.

Cara Pembuatan Sistem NLC Ekstrak Etanol 96\% Daun Chrysanthemum cinerariifolium (Trev.) Vis.
Metode yang digunakan dalam penelitian ini adalah High Shear Homogenization. Sistem NLC ekstrak etanol $96 \%$ daun Chrysanthemum cinerariifolium (Trev.) Vis dibuat dengan cara melelehkan fase lipid (Monostearin dan Asam Oleat) dengan menggunakan variasi lipid berbeda $(10 \%, 20 \%, 30 \%)$ pada suhu $75^{\circ} \mathrm{C}$. Pada saat yang sama, masing-masing bahan pada fase air (Tween-80, Span-80 dan dapar fosfat $\mathrm{pH} \mathrm{7,4)} \mathrm{dipanaskan} \mathrm{pada}$ suhu $80^{\circ} \mathrm{C}$ selama 15 menit. Diangkat ketiga bahan kemudian dilarutakan ekstrak etanol $96 \%$ daun Chrysanthemum cinerariifolium (Trev.) Vis dalam dapar fosfat hingga larut, kemudian disaring untuk mencegah residu. Filtrat yang telah didapatkan, dicampurkan dalam Span 80 dan Tween 80 kemudian, di panaskan lagi pada suhu $80^{\circ} \mathrm{C}$ selama 10 menit. Disisi lain disiapkan alat Ultra Turrax IKA T25 diatas fase lipid, dinyalakan alat dengan kecepatan $3400 \quad \mathrm{rpm}$ sambil dicampurkan fase air secara perlahan ke dalam fase lipid dengan suhu $75^{\circ} \mathrm{C}$ dilakukan pengadukan selama 30 menit

Tabel 1. Formula sistem NLC Ekstrak Etanol 96\% Daun Chrysanthemum cinerariifolium (Trev.)Vis.

\begin{tabular}{llcccc}
\hline \multirow{2}{*}{ No } & \multicolumn{1}{c}{ Bahan } & \multirow{2}{*}{ Fungsi } & \multicolumn{3}{c}{ Konsentrasi (\%)b/b) } \\
\cline { 4 - 6 } & & Bahan Aktif & 1 & 1 & F2 \\
\hline $\mathbf{1}$ & Ekstrak Daun Krisan Putih & Lipid Padat & 6 & 12 & 18 \\
$\mathbf{2}$ & Monostearin & Lipid Cair & 4 & 8 & 12 \\
$\mathbf{3}$ & Asam Oleat & Surfaktan & 0,55 & 0,55 & 0,55 \\
$\mathbf{4}$ & Tween 80 & Surfaktan & 9,45 & 9,45 & 9,45 \\
$\mathbf{5}$ & Span 80 & Fase Air & \multicolumn{3}{c}{ Sampai 100 } \\
$\mathbf{6}$ & Dapar Fosfat $\mathrm{pH} 7,4$ & &
\end{tabular}

\section{Keterangan :}

Formula I : Sistem NLC Krisan dengan konsentrasi lipid sebesar 10\% (Formula 1)

Formula II : Sistem NLC Krisan dengan konsentrasi lipid sebesar 20\% (Formula 2)

Formula III : Sistem NLC Krisan dengan konsentrasi lipid sebesar 30\% (Formula 3) 
Setelah 30 menit didapatkan sediaan preemulsi Nanostructured Lipid Carrier, pre emulsi yang sudah dihomogenisasi, diangkat kemudian dihomogenkan lagi dengan magnetic stirrer dengan kecepaan 800 rpm hingga suhu mencapai $33^{\circ} \mathrm{C}$. Didapatkan sediaan Nanostructured Lipid Carrier (NLC) daun Chrysanthemum cinerariifolium (Trev.) Vis.

\section{Evaluasi Karakteristik Fisikokimia Sistem NLC Ekstrak Etanol 96\% Daun Chrysanthemum cinerariifolium (Trev.)Vis.}

\section{Pemeriksaan Organoleptis}

Pemeriksaan organoleptis dilakukan secar visual. Proses pengamatan dilihat dari konsistensi, warna, bau dan homogenitas NLC. Nanostructured Lipid Carrier (NLC) yang stabil ditandai dengan konsistensi yang sesuai, warna yang sesuai bahan aktif, bau yang tidak tengik dan homogen (14).

\section{Pengukuran pH}

Pengukuran $\mathrm{pH}$ masing-masing formula dilakukan dengan menggunakan pH meter. Diambil $10 \mathrm{ml}$ sistem NLC ekstrak etanol $96 \%$ daun Chrysanthemum cinerariifolium (Trev.)Vis, kemudian elektroda $\mathrm{pH}$ meter dimasukkan ke dalam sistem NLC ekstrak etanol $96 \%$ daun Chrysanthemum cinerariifolium (Trev.)Vis lalu dicatat angka yang ditunjukkan $\mathrm{pH}$ meter (15).

\section{Pengukuran Viskositas}

Pengukuran viskositas sampel NLC dilakukan menggunkan alat viskometer brookfield cone and plate LV DV3T (America, AMETEX,Inc.) Pengukuran viskositas dilakukan guna mengetahui nilai kekentalan dari sampel sistem NLC karena pengaruh penambahan bahan lain seperti surfaktan serta pengaruh dari teknik pembuatan. Pengukuran viskositas menggunakan viskometer brookfield cone and plate (16). Plate stasioner membentuk bagian bawah cangkir sampel yang dapat dipindahkan, dan diisi dengan 0,5-2,0 $\mathrm{ml}$ sampel sistem NLC. Sampel NLC diletakkan pada sample cup, sampel dipastikan bebas gelembung dan tersebar merata pada permukaan cup. Selanjtnya sample cup dipasang kembali pada cone viscometer, viscometer dinyalakan, lalu dibiarkan beberapa saat sampai pembacaan stabil. Nilai viskositas pada sistem NLC memiliki rentang sebesar 32,5-2499,5 cPs (7).

\section{Pengukuran Ukuran Partikel}

Pengukuran ukuran partikel dilakukan menggunakan alat Particle Size Analyzer (PSA) Delsa ${ }^{\mathrm{TM}}$ Nano (USA, Microtac). Sampel yang akan dianalisis terlebih dahulu ditimbang sampel NLC seberat 1 g. kemudian ditambahkan aquades sebanyak $10 \quad \mathrm{ml}$, kemudian dihomogenkan. Sampel yang telah homogen dimasukkan ke dalam kuvet. Kuvet yang digunakan harus bersih dari busa dan lemak. Kuvet yang telah diisi sampel dimasukkan ke dalam sample holder. Alat dinyalakan dan dipilih menu particle size. Alat akan mengukur sampel selama 10 menit. Data yang dihasilkan merupakan ukuran partikel yang dihitung dari fluktuasi rata-rata intens hamburan cahaya (7).

\section{Pengukuran Persen Efisiensi Penjebakan}

Ditimbang 1 g NLC, kemudian ditambahkan dapar fosfat $\mathrm{pH} \mathrm{7,4 \pm 1}$ hingga volume $10 \mathrm{ml}$. Pengukuran efis 
efisiensi penjebakan dilakukan menggunakan spektrofotometri UV VIS. Hasil pemisahan berupa ekstrak yang terjebak dalam sistem NLC akan mengendap setelah dipisahkan dengan sentrifus pada 2500 rpm selama 45 menit. Ekstrak krisan yang tidak terjebak dalam sistem NLC akan terdispersi dalam dapar fosfat $\mathrm{pH} 7,4 \pm 1$ sebagai supernatan. Selanjutnya dilakukan pengukuran konsentrasi obat bebas pada fase air pada dispersi NLC. Blanko yang digunakan ialah sistem NLC tanpa penambahan ekstrak dan dipreparasi sesuai sampel uji. Selanjutnya dihitung dengan menggunakan rumus : (7)

Keterangan

$\mathrm{EE}(\%)=((\mathrm{Ct}-\mathrm{Cf} / \mathrm{Ct})) \times 100 \%$

$\mathrm{Ct}$ : Jumlah bahan obat yang digunakan

Cf : Jumlah bahan obat yang berada pada fase air

\section{HASIL DAN PEMBAHASAN}

\section{EVALUASI ORGANOLEPTIS}

Uji organoleptik dimaksudkan untuk mengetahui tampilan fisik sediaan Nanostructured Lipid Carrier (NLC) yang meliputi warna, bau, konsistensi dan homogenitas. Pengujian ini dilakukan secara visual tanpa bantuan alat khusus. Pada hasil evaluasi warna diperoleh seadiaan dengan warna yang berbeda-beda hal ini dapat terjadi karena faktor kelarutan senyawa dalam ekstrak daun Chrysanthemum cinerariifolium (Trev.) Vis. Senyawa antioksidan pada ekstrak etanol $96 \%$ daun Chrysanthemum cinerariifolium (Trev).Vis menghasilkan senyawa golongan flavonoid yang meliputi kaemferitrin, kaemferol, isorhamnetin, genistein dan orphenadrin (11). Kelima senyawa tersebut memiliki kelarutan yang sama, yakni kelarutan yang rendah dalam air $(<1 \mu \mathrm{g} / \mathrm{ml})$ dan dalam lemak $(17,18,19,12)$. Karena media penjerap obat adalah fase lemak, semakin pekat warna yang dihasilkan pada lipid dengan konsentrasi rendah sehingga semakin banyak senyawa yang larut pada fase air. Begitupun sebaliknya, semakin banyak fase lemak semakin banyak senyawa yang terjerap sehingga warna menjadi pucat (20).

Aroma khas campuran ekstrak dan minyak merupakan hasil dari pencampuran bahan baku formula yang jumlahnya dominan terdiri dari ekstrak etanol 96\% Daun Chrysanthemum cinerariifolium (Trev.) Vis, lipid padat monostearin dan lipid cair asam oleat. Konsistensi sediaan sistem NLC dipengaruhi oleh konsentrasi lipid menurut hasil pengamatan secara visual, konsistensi sediaan menjadi memadat seiring dengan meningkatnya

Tabel 2. Hasil evaluasi organoleptis sistem NLC Daun Chrysanthemum cinerariifolium (Trev.) Vis.

\begin{tabular}{ccccc}
\hline $\begin{array}{c}\text { Konsentrasi } \\
\text { Lipid pada } \\
\text { Formula }\end{array}$ & Warna & Bau & Konsistensi & Homogenitas \\
\cline { 2 - 5 } $\mathbf{1 0 \%}$ & Hijau pekat & $\begin{array}{c}\text { Berbau seperti ekstrak dan khas } \\
\text { minyak }\end{array}$ & Kental cair & Homogen \\
$\mathbf{2 0 \%}$ & Hijau & $\begin{array}{c}\text { Berbau seperti ekstrak dan khas } \\
\text { minyak }\end{array}$ & Semisolid & Homogen \\
$\mathbf{3 0 \%}$ & Hijau pucat & $\begin{array}{c}\text { Berbau seperti ekstrak dan khas } \\
\text { minyak }\end{array}$ & Semisolid & Homogen \\
\hline
\end{tabular}


konsentrasi lipid. Lipid mempengaruhi tingkat viskositas sistem NLC, meningkatnya konsentrasi lipid meningkatkan nilai viskositas berhubungan dengan konsistensi sediaan ditandai dengan semakin memadatnya sediaan (2). Selanjutnya yakni uji homogenitas, uji homogenitas bertujuan untuk melihat dan mengetahui tercampurnya bahan-bahan dari sediaan NLC. Pengujian ini dilakukan secara visual dengan cara mengamati bahanbahan dari sediaan NLC. Pengujian ini dilakukan secara visual dengan cara mengamati rata atau tidaknya bahan NLC. Hasil penelitian menunjukkan tidak adanya gumpalan atau pemisahan fase, sediaan yang homogen dimungkinkan bahan-bahan telah tercampur secara homogen dan jumlah pengemulsi yang digunakan cukup untuk menstabilkan emulsi (14).

\section{EVALUASI NILAI pH}

Evaluasi nilai $\mathrm{pH}$ berdasarkan hasil pengukuran $\mathrm{pH}$ pada ketiga formula, tidak menunjukkan perbedaan yang terlalu jauh dan masih dalam rentang nilai $\mathrm{pH}$ untuk sediaan oral maupun sediaan topikal. Nilai $\mathrm{pH}$ pada formulasi sistem Nanostr Nanostructured Lipid Carrier (NLC) berkisar antara 6,7 sampai dengan 7 menunjukkan nilai $\mathrm{pH}$ mendekati netral. Hal tersebut dikarenakan komposisi bahan yang digunakan dalam sistem (1). Komposisi bahan Nanostructured Lipid Carrier (NLC) memiliki nilai $\mathrm{pH}$ yang berbeda seperti dapar fosfat dengan konsentrasi paling besar dalam sistem memiliki $\mathrm{pH} 7,4$ untuk fase lipid, monostearin memiliki pH kisaran 8-10, asam oleat 4,4, surfaktan tween 80 memiliki pH 5-7 dan surfaktan span 80 pH 6-8 (21). Oleh karena itu, perbedaan konsentrasi pada formulasi sistem Nanostructured Lipid Carrier (NLC) menunjukkan nilai yang tidak berbeda nyata $(1,21)$. Pada formula konsentrasi $10 \%$ dan $20 \%$ didapatkan nilai rata-rata $\mathrm{pH} 7,0 \pm 0,12$ dan $6,7 \pm 0,17$ yang tergolong dalam $\mathrm{pH}$ netral atau sedikit basa, $\mathrm{pH}$ tersebut cocok digunakan pada sediaan NLC oral antikanker sehingga penyerapannya lebih banyak pada bagian ileum dan usus besar yang memiliki rentang $\mathrm{pH}$ optimal sebesar 68 (22) sedangkan pada formula 3 didapatkan rata-rata nilai $\mathrm{pH}$ sebesar 6,8 $\pm 0,2$ sehingga cocok untuk sediaan topikal NLC yang memiliki rentang $\mathrm{pH}$ 4 hingga 7 (23).

\section{EVALUASI VISKOSITAS}

Evaluasi viskositas pengukuran viskositas dilakukan untuk mengtahui tingkat kekentalan sistem Nanostructured Lipid Carrier. Viskositas formulasi sistem Nanostructured Lipid Carrier berkisar pada 32,5-2499,5 cPs (Annisa, dkk., 2018). Viskositas NLC dipengaruhi oleh konsentrasi penyusun NLC terutama konsentrasi lipid padat dan lipid cair dan alat yang digunakan pada proses evaluasi. Peningkatan konsentrasi lipid mengarah pada peningkatan interaksi partikel-partikel sehingga menghasilkan struktur yang lebih kaku (25). Untuk alat yang digunakan saat evaluasi yakni semakin besar nilai $\mathrm{R}$ pada tipe spindle alat uji, semakin mudah untuk menganalisis sediaan berkonsistensi tinggi. Berdasarkan hasil evalusi, pada formula konsentrasi $10 \%$ didapatkan nilai viskositas lebih tinggi dengan nilai rata-rata 55,66 $\pm 2,84 \mathrm{cPs}$, dibandingkan dengan formula $20 \%$ dan $30 \%$ yang memiliki nilai rata-rata viskositas lebih rendah yakni $28,86 \pm 3,91 \mathrm{cPs}$ dan 28,57 $\pm 16,85$ cPs. Hal ini dapat terjadi 
Tabel 3. Hasil evaluasi $\mathrm{pH}$ sistem NLC daun Chrysanthemum cinerariifolium (Trev.) Vis.

\begin{tabular}{cc}
\hline $\begin{array}{c}\text { Konsentrasi Lipid } \\
\text { pada Formula }\end{array}$ & $\begin{array}{c}\text { Uji pH sistem NLC daun Chrysanthemum } \\
\text { cinerariifolium } \text { (Trev.) Vis. }\end{array}$ \\
\hline $\mathbf{1 0} \%$ & $7,0 \pm 0,12$ \\
$\mathbf{2 0 \%}$ & $6,7 \pm 0,17$ \\
$\mathbf{3 0 \%}$ & $6,8 \pm 0,2$ \\
\hline
\end{tabular}

Tabel 4. Hasil evaluasi viskositas sistem NLC daun Chrysanthemum cinerariifolium (Trev.) Vis

\begin{tabular}{cc}
\hline $\begin{array}{c}\text { Konsentrasi Lipid } \\
\text { pada Formula }\end{array}$ & $\begin{array}{c}\text { Hasil Uji Viskositas NLC daun } \\
\text { Chrysanthemum cinerariifolium (Trev.) Vis. }\end{array}$ \\
\hline $\mathbf{1 0} \%$ & $55,66 \pm 2,84 \mathrm{cPs}$ \\
$\mathbf{2 0 \%}$ & $28,86 \pm 3,91 \mathrm{cPs}$ \\
$\mathbf{3 0 \%}$ & $28,57 \pm 16,85 \mathrm{cPs}$ \\
\hline
\end{tabular}

karena ketidak cocokan alat pada proses evaluasi viskositas. Berdasarkan uji secara organoleptis, hasil dari pengamatan konsistensi pada formula 2 dan 3 menunjukkan kosistensi sediaan semisolid seperti krim. Evaluasi nilai viskositas menggunakan viskometer Brookfield pada sediaan krim menggunakan spindel R6 atau R7 (26).

\section{EVALUASI UKURAN PARTIKEL}

Pengukuran partikel merupakan karakteristik paling penting untuk produk nanopartikel yang berpengaruh terhadap kestabilan fisik, kelarutan dan kinerja biologi (27). Proses pengukuran partikel dilakukan menggunakan instrumen Particle Size Analyzer (PSA), PSA seri zetasizer paling banyak digunakan untuk pengukuran ukuran nanopartikel, koloid, protein, zeta potensial dan bobot molekul (28). Nanostructured Lipid Carrier memiliki rentang ukuran partikel sebesar 10-1000 nm (29). Dari data yang ada diketahui bahwa ukuran partikel NLC yang paling kecil adalah formula dengan konsentrasi lipid 30\% dengan nilai ukuran partikel rata-rata $4676 \pm 2215,75 \mathrm{~nm}$. Faktor penambahan lipid cair pada formula berperan dalam mengecilkan ukuran, dengan meningkatkan konsentrasi lipid cair maka ukuran partikel NLC berkurang (30), hal serupa juga dilaporkan bahwa penambahan lipid cair ke lipid padat cenderung mendorong pembentukan populasi partikel kecil, yang mungkin disebabkan oleh peningkatan mobilitas molekul matriks setelah penambahan lipid cair (31). Sedangkan pada formula dengan konsentrasi $10 \%$ dan $20 \%$ diperoleh nilai ukuran partikel rata-rata $5530 \pm 320,47$ $\mathrm{nm}$ dan $5337 \pm 671,44 \mathrm{~nm}$. Nilai ukuran partikel yang didapatkan berada diluar rentang ukuran sistem nanopartikel namun masih termasuk di dalam ukuran mikropartikel yang mana pada sediaan mikro memiliki rentang ukuran partikel sebesar 0,1-10 $\mu \mathrm{m}$ atau 100-10.000 nm (32). Ketidaksesuaian ini dapat terjadi karena beberapa faktor bahan aktif 
formula pada sistem NLC, daun Chrysanthemum cinerariifolium (Trev.) Vis, digunakan bahan aktif yakni ekstrak etanol $96 \%$ daun Chrysanthemum cinerariifolium (Trev.) Vis yang mana terkandung berbagai senyawa multicompound di dalam ekstrak. Hal ini sesuai dengan yang didapatkan pada analisis ukuran partikel menunjukkan ukuran sistem NLC yang bermuatan obat secara signifikan lebih besar daripada sistem NLC basis karena bahan aktif terjerap pada sistem (33). Faktor yang juga mempengaruhi ukuran partikel yakni peningkatan kecepatan homogenisasi, yang terjadi karena peningkatan gaya berubahan bentuk partikel zat di bawah tekanan (deformasi) semakin tinggi kecepatan semakin banyak tekanan yang diperoleh oleh sistem sehingga menghasilkan ukuran partikel yang kecil (30). Namun hal tersebut belum bisa di aplikasikan dalam sediaan NLC ekstrak etanol daun Chrysanthemum cinerariifolium (Trev.) Vis, karena jika kecepatan pengadukan ditingkatkan, akan menghasilkan busa pada sediaan sehingga dapat mengganggu stabilitas dari sediaan.

\section{EVALUASI PERSENTASE EFISIENSI PENJEBAKAN OBAT}

Efisiensi penjebakan atau Entrapment efficiency merupakan salah satu metode karakterisasi untuk mengetahui seberapa besar presentase zat aktif yang terjebak di dalam sisem NLC (7). Efisisensi penjebakan merupakan presentase bahan aktif yang terjebak di dalam partikel lipid. Untuk sediaan lipofilik, biasanya memiliki nilai EE antara 90-98\% (34) dan untuk sediaan yang hidrofilik memiliki nilai EE sebesar 30-50\% (35). Penentuan efisiensi penjebakan sistem NLC daun Chrysanthemum cinerariifolium (Trev.) Vis dilakukan dengan metode sentrifugasi dan dianalisis dengan spektrofotometri UVVIS. Berdasarkan analisis hasil pengamatan terdapat perbedaan efisiensi penjebakan secara bermakna dari ketiga formula, semakin tinggi kadar asam oleat semakin besar efisiensi penjebakannya dengan hasil pada formula persentase lipid $10 \%$ didapatkan $33,55 \%$, formula lipid $20 \%$ didapatkan nilai persentase $38,77 \%$ dan formula lipid $30 \%$ dengan persentase $83,75 \%$. Hal ini dapat disebabkan karena asam oleat yang berfungsi sebagai lipid cair yang dapat menurunkan keteraturan kisi kristal monostearin sehingga dapat memuat bahan obat lebih banyak (36)

Tabel 6. Hasil evaluasi persentase efisiensi penjebakan obat sistem NLC daun Chrysanthemum cinerariifolium (Trev.) Vis.

\begin{tabular}{cc}
\hline $\begin{array}{c}\text { Konsentrasi Lipid } \\
\text { pada Formula }\end{array}$ & $\begin{array}{c}\text { Hasil Uji Efisiensi Penjebakan Sistem NLC daun } \\
\text { Chrysanthemum cinerariifolium } \\
\text { (Trev.) } \\
\text { Vis. }\end{array}$ \\
\hline $\mathbf{1 0 \%}$ & $33,55 \%$ \\
$\mathbf{2 0 \%}$ & $38,77 \%$ \\
$\mathbf{3 0 \%}$ & $83,75 \%$ \\
\hline
\end{tabular}


selain itu, lipid padat juga berfungsi sebagai media penjerapan lebih banyak sehingga muatan obat lebih banyak. Untuk formula dengan efisiensi penjebakan obat $33,55 \%$ dan $38,77 \%$ nilai tersebut masih aman, karena masih termasuk dalam rentang nilai efisiensi penjebakan sediaan hidrofilik sebesar 30-50\% (35) sehingga cocok digunakan untuk sediaan oral karena sifat yang hidrofilik dan memiliki hambatan pelepasan yang kecil sehingga obat lebih mudah larut dalam air dan dengan mudah terdisolusi dalam cairan gastrointestinal untuk kemudian diserap oleh tubuh (37). Sedangkan pada sediaan dengan konsentrasi lipid 30\% cocok digunakan pada sediaan topikal NLC dengan persen nilai efisiensi penjebakan sebesar $83,75 \%$, nilai ini tegolong dalam sediaan topikal sistem NLC yang memiliki rentang sebesar 90-98\% (34).

\section{KESIMPULAN}

1) Sistem NLC daun Chrysanthemum cinerariifolium (Trev.) Vis menggunakan lipid padat Monostearin dan lipid cair Asam Oleat menghasilkan karakteristik fisikokimia yang baik pada hasil pemeriksaan organoleptis, nilai $\mathrm{pH}$, dan persentase efisiensi penjebakan obat. Sedangkan, pada pemeriksaan viskositas dan ukuran partikel belum menghasilkan nilai yang baik dikarenakan ketidakcocokan alat saat proses evaluasi dan faktor dari kandungan bahan aktif sistem NLC.

2) Berdasarkan hasil penelitian didapatkan karakteristik fisikokimia terbaik pada konsentrasi lipid 10\% sebagai sistem Nanostructured Lipid Carrier (NLC) daun Chrysanthemum cinerariifolium (Trev.) Vis sediaan oral antikanker

\section{SARAN}

Saran yang dapat diberikan untuk penelitian ini adalah:

1) Untuk pengembangan Novel Drug Delivery System sistem Nanostructured Lipid Carrier ekstrak etanol 96\% daun Chrysanthemum cinerariifolium (Trev.)
Vis cocok ditujukan untuk sediaan berukuran mikropartikel

2) Perlu dilakukan fraksinasi pada senyawa daun Chrysanthemum cinerariifolium (Trev.) Vis yang dipilih guna memperbaiki ukuran partikel.

3) Digunakan alat yang sesuai pada evaluasi uji karakteristik nilai viskositas.

\section{DAFTAR PUSTAKA}

1. Rohmah M, Raharjo S, Hidayat C, Martien R. Formulasi dan Stabilitas Nanostructured Lipid Carrier dari Campuran Fraksi Stearin dan Olein Minyak Kelapa Sawit. Jurnal Aplikasi Teknologi Pangan. 2019;8(1).

2. Muller R H, Radtke M, Wissing SA. Nanostructured Lipid Matrices for Improved Microencapsulation of Drugs". Internatonal Journal Pharm. Department of Pharmaceutics, Biopharmaceutics and Biotechnology. 2002;242(1-2):121-128.

3. Hung, L. C., Basri, M., Tejo, B. A., Ismail, R., Nang, H. L. L., dkk. An improved method for the preparations of nanostructured lipid carriers containing heat-sensitive bioactives. Colloids and Surfaces B: Biointerfaces. 2011.87(1):180- 186.

4. Mohanraj, V.J. and Chen, Y. Nanoparticle - A Review. Tropical J. of Pharmaceutical Research. 2007;5(1): 561-573.

5. Shah, N. V., Seth, A. K., Balaraman, R., Aundhia, C. J., Maheshwari, R. A., Parmar, G. R. Nanostructured lipid carriers for oral bioavailability enhancement of raloxifene: Design and in vivo study. Journal of Advanced Research. 2016;1 7(3): 423-434.

6. Qian C, Decker E.A, Xiao H, Mc Clements D.J. Solid Lipid Nano Particles : Effect of Carrier Oil and Emulsifier Type on Phase Behavior and Physical Stability. $J$ Am Oil Chem Soc. 2011;89(1): 17-28 
7. Annisa R, Esti H, dan Melani D. Pengembangan Sistem Nanostructured Lipid Carriers (NLC) Meloxicam dengan Lipid Monostearin dan Miglyol 808 Menggunakan Metode Emulsifikasi. J.Trop.Pharm.Chem. 2016;3(3).

8. Primahadi, Yoga. Pengaruh Variasi Jenis Minyak Pada Emulsi Air Dalam Minyak Menggunakan Emulsifier Fosfolipid. Skripsi. Universitas Diponegoro. 2006.

9. Hu F.Q, Jiang S.P, Yuan H, Ye Y.Q, Zeng S. Preparation and characterization of stearic acid nanostructured lipid carriers by solvent diffusion method in an aqueous system. Colloids and Surfaces B. Biointerfaces. 2005;45(3-4): 167-173.

10. Aisiyah S, Harjanti R, Nopiyanti V. Pengaruh Panjang Rantai Karbon Lipid Padat terhadap Karkteristik Nanostructured Lipid Carrier Revesratrol. Journal of Pharmaceutical Science and Clinical Research. 2019;02(4): 69-81.

11. Inayatin L. A. Pengaruh Pemberian Ekstrak Etanol 96\% Daun Krisan (Chrysanthemum cinerariifolium (Trev.) Vis) Terhadap Induksi Apoptosis Daun Penghambatan Siklus Sel pada Sel Kanker Payudara T47D. Skripsi. Universitas Islam Negeri Maulana Malik Ibrahim Malang. 2018.

12. Zhao G, Duan J, Xie Y, Lin G, Luo H, Li $\mathrm{G}$, dkk. Effect of solid dispersion and self-emulsifiying formulations on the solubility, dissolution, permeability and pharmacokinetics of isorhamnetin, quercetin and kaemferol in total flavones of Hippophae rhamnoides L. Drug Development and Industrial Pharmacy. 2013;39(7): 1037-1045.

13. Ramadon D dan Mun'im A. Pemanfaatan Nanoteknologi dalam Sistem Pengahntaran Obat Baru untuk Produk Bahan Alam. Jurmal Ilmu Kefarmasian Indonesia. 2016;2(14).

14. Suprobo G, Rahmi D. Pengaruh Kecepatan Homogenisasi Terhadap Sifat Fisika dan Kimia Krim Nanopartikel
Dengan Metode High Speed Homogenization. Jurnal Litbang Industri. 2015;5(1).

15. Hendradi E, Rosita N, Rahmadhanniar E. Effect of Lipid Ratio of Stearic Acid And Oleic Acid on Characteristics of Nanostructured Lipid Carrier (NLC) System of Diethylammonium Diclofenac. Indonesian $J$ Pharm. 2017;28(4).

16. Anggraeni Y, Haryanto Y I, Hendradi E. Physical and Chemical Characteristics of Meloxicam From Nanostrudtured Lipid Carriers System Using Some Concentration Ratios of Monostearin and Alpha-tocopherol Acetate Lipid Matrix. Asian Journal of Pharmaceutical and Clinical Research. 2017;10(2).

17. Kaur H dan Kaur G.2014.Review Article: A Critical Apprasial of Solubility Enhancement Techniques of Polyphenols. Journal of Pharmaceutics. Hindawi Publishing Corporation.

18. Omer S L, Ali J R. Assay of Orphenadrine Citrate in Pharmaceuticals via Ekstraction-Spectrophotometric Method. Iraqi Journal of Science. 2018;59(3A).

19. Aditya NP, Shim M, Lee I, Lee YJ, Hyeong Im M, Ko S. Curcumin and Genistein Coloaded Nanostructured Lipid Carriers: in Vitro Digestion and Antiprostate Cancer Activity. Journal of Agricultural and Food Chemistry. 2013;61(8): 1878-1883.

20. Afina F.A.. Pengaruh Kadar Asam Oleat Pada Sistem NLC Dengan Lipid Setil Alkohol: Asam Oleat Dibandingkan Dengan SLN Terhadap Laju Pelepasan APMS .Skripsi. Jurusan Farmasi. Universitas Airlangga.2015.

21. Rowe C.R, Sheskey J P, Owen C S. Handbook of Pharmaceutical Excipients. Fifth Edition. Pharmaceutical Press. 2009.

22. Nasirizadeh S, Nikouei-M B. Solid Lipid Nanoparticles and Nanostructured Lipid Carriers in Oral Cancer Drug Delivery. 
Journal of Drug Delivery Science and Technology.

23. Lambers H, Piessens S, Bloem H, Pronk, Finked $\mathrm{P}$. Natural skin surface $\mathrm{pH}$ is on average below 5 , which is beneficial for its resident flora. International Journal of Cosmetic Science. 2006;28(5): 359370.

24. Annisa R, Dewi Melani Hariyadi, Esti Hendradi. Evaluation Of The Physical Stability Of Nanostructured Lipid Carrier (NLC) Meloxicam Before And After Strorage 40 Days. International Journal Of Drug Delivery Technology. 2018;8(2).

25. Lippacher, A., Muller, R.H. And Mader K. Liquid And Semisolid SLN TM Dispersion For Topical Application, Rheological Characterization.Eur. J.Pharm.Biopharm. 2004;58(3): 561567.

26. Dewi Rosmala, Anwar Effionora, K.S Yunita. Uji Stabilitas Fisik Formula Krim Yang Mengandung Ekstrak Kacang Kedelai (Glycine Max). Original Article Pharm Sci Res. Depok Fakultas Farmasi Universitas Indonesia. 2016

27. Kumar dan Lakshmi."Nano-Suspension Technology: A review". International Journal of Pharmacy and Pharmaceutical Sciences. 2010;2(4).

28. Nuraeni W, Daruwati I, Maria W E, Sriyani E M. Verifikasi Kinerja Alat Particle Size Analyzer (PSA) Horiba LB550 Untuk Penentuan Distribusi Ukuran Nanopartikel.Prosiding Seminar Nasional Sains dan Teknologi Nuklir.PTNBR-BATAN. 2013.

29. Zhang T, Chen J, Zhang Y, Shen Q, Pan W. Characterization and Evaluation of Nanostructured Lipid Carrier as a Vehicle for Oral Delivery of Etoposide. European Journal of Pharmaceutical Sciences. 2011;43(3): 174-179.

30. R.Gardouh, Ahmed, Faheim, Samar, Noah, Ahmed, dkk. Influence Of Formulation Factors On The Size Of Nanostructured Lipid Carriers And Nanoemulsions Prepared By High Shear
Homogenization. International Journal Of Pharmacy And Pharmaceutical Sciences. 2018;10(4): 61.

31. $\mathrm{Mu} \mathrm{L}$, Feng S. A Novel Controlled Release Formulation for the Anticancer Drug Paclitaxel (Taxol):PLGA Nanoparticles Containing Vitamin. E. Journal Controlled Release. 2003;86(1): 33-48.

32. Zuhro Talida N. Karakterisasi Fisikokimia dan Uji Pelepasan Alfa Arbutin Pada Sediaan Mikroemulgel Dengan Variasi Konsentrasi Carbopol 940 .Skripsi.Universitas Islam Negeri Maulana Malik Ibrahim Malang. 2019.

33. Zardini A A, Mohebbi M, Farhoosh R, dan Bolurian S. Production and Characterization of Nanostructured Lipid Carrier and Solid Lipid Nanoparticles Containing Lycopene for Food Fortification. Journal Food Sci Technol. 2018;55(1).

34. Rahmawan T. Gusta, Rosita Noorma.T.E. Characterization Of Solid Lipid Nanoparticle P-Methoxy Cinnamic Acid (PMCA) Formulated With Different Lipid Component Stearic Acid And Cetyl Alcohol. Pharma Scientia. 2012;1(1): 22-29.

35. Ghadiri M, Fatemu S, Vatanara A, Doroud D, Najafabadi R A, Darabi M, dkk. Loading Hydrophilic Drug in Solid Lipid Media as Nanoparticles: Statistical Modeling of Entrapment Efficiency and Particle Size. International Journal of Pharmaceutics. 2012;424(1-2): 128137.

36. Zhuang $\mathrm{CY}$, Li N, Wang $\mathrm{W}, \mathrm{Z}$ hang $X N$, Pan WS, Peng JJ. Preparation and Characterization of Vinpocetine Loaded Nanostructured Lipid Carriers (NLC) for Improved Oral Bioavailability. International Journal of Pharmaceutics. 2010;394(1): 179185.

37. Nurfauziyah $R$ dan Rusdiana $T$. Review: Formulasi Nanoemulsi Untuk Meningkatkan Kelarutan Obat Lipofilik". Farmaka. 2018;16(1) 